\title{
El Cenáculo ecuatoriano Dada de Portoviejo
}

\author{
The Ecuadorian Dada Cenacle of Portoviejo
}

\author{
José Miguel Haro Zambrano \\ Universidad Católica de Argentina \\ Buenos Aires, Argentina \\ Universidad Andina Simón Bolívar, Sede Ecuador \\ Quito, Ecuador
}

Artículo de investigación

https://doi.org/10.32719/13900102.2021.49.6

Fecha de recepción: 13 de abril de 2020

Fecha de aceptación: 5 de junio de 2020 


\section{RESUMEN}

Este escrito es el resultado de una investigación que se propuso comprender el surgimiento en 1922 del dadaísmo en la ciudad de Portoviejo, capital de la provincia de Manabí, Ecuador. Considerando que esta ciudad de la Costa ecuatoriana en ese entonces era predominantemente agreste y era el escenario de violentas disputas entre liberales y conservadores, resultaba poco probable que una manifestación artística de este tipo fuera posible, lejos de los grandes centros culturales y las metrópolis industrializadas. Para explicar el surgimiento de esta corriente poética, el autor explora el desarrollo histórico y estético del dadaísmo y su transmisión a través de revistas culturales que establecieron el nexo entre las grandes ciudades europeas como Zúrich, París y Madrid con el Ecuador y la ciudad de Portoviejo. Además, el autor sugiere un posible develamiento de los nombres reales que encubren hasta ahora los pseudónimos con los que se presentaron los dadaístas de Portoviejo.

Palabras clave: Ecuador, dadaísmo, ultraísmo, Hugo Mayo, Cenáculo, Dada, espíritu nuevo, Portoviejo, Manabí, poesía, vanguardia.

\section{ABSTRACT}

This paper is the result of an investigation that set out to understand the emergence of Dadaism in 1922 in the city of Portoviejo, capital of the province of Manabí, Ecuador. Considering that this city on the Ecuadorian coast was at that time predominantly rural and was the scene of violent disputes between liberals and conservatives, it was unlikely that an artistic manifestation of this type might be possible, far from the great cultural centers and industrialized metropolises. To explain the emergence of this poetic current, the author explores the historical and aesthetic development of Dadaism and its transmission through cultural magazines that established the link between large European cities such as Zurich, Paris and Madrid with Ecuador and the city of Portoviejo. In addition, the author suggests a possible unveiling of the real names that have so far been concealed by the pseudonyms under which the Portoviejo Dadaists presented themselves.

KeYwords: Ecuador, Dadaism, ultraism, Hugo Mayo, Cenacle, Dada, new spirit, Portoviejo, Manabí, poetry, avant-garde.

El dadaísmo ecuatoriano surgió en 1922 en la ciudad de Portoviejo, capital de la provincia de Manabí, como un esfuerzo grupal de autores jóvenes, de los cuales dos participaron con sus nombres civiles, cuatro con pseudónimos y uno firmó su única colaboración como "Dadaísta Aficionado". Al ser Portoviejo una zona predominantemente agreste, resultaba extraño el surgimiento de un dadaísmo ajeno a los horrores de las grandes guerras mundiales y a la industrialización. Sin embargo, como se demostrará en el presente artículo, el reconocimiento de una orientación introspectiva, en lugar de una confrontativa del dadaísmo, explica el surgimiento de esta corriente en esta ciudad del Ecuador. Los pseudónimos de Rodrigo 
Enero, Jorge Marzo, José Julio y Alfredo Septiembre, poetas que participaban en una de las variadas secciones de la revista Iniciación (1921-28), aún hoy resguardan la identidad real de los autores, pero por medio de un análisis del estilo, se puede reconocer algunos rasgos distintivos que sugieren un posible develamiento de la identidad de los poetas.

La gran cantidad de expresiones culturales que aparecieron en Europa y América en 1922 es llamativa. En especial por la coincidente aparición de obras y eventos relevantes en el campo de lo que se conoce como literatura de vanguardia. En Irlanda James Joyce publicó Ulysses, en Francia apareció Veinte poemas para ser leidos en el tranvía de Oliverio Girondo, en São Paulo se celebró la Semana de Arte Moderno y en Perú César Vallejo publicó Trilce. Con la aparición de la poesía dadaísta, desde Ecuador se sumaba otra manifestación curiosa en este año particular y, además, se podría agregar a la lista la malograda obra poética El zaguán de aluminio de Hugo Mayo, cuya confusa historia declara que el manuscrito misteriosamente desapareció de la imprenta en una noche de luna cortada. ${ }^{1}$ En Ecuador este año tiene una mayor relevancia ya que aparecieron obras de gran importancia en el campo de la política y la sociología. En este año un joven José María Velasco Ibarra se graduaba de abogado con su tesis El sindicalismo y Pío Jaramillo Alvarado publicaba El indio ecuatoriano. ${ }^{2}$ No solo a nivel de publicaciones este año es importante para el Ecuador: el 15 de noviembre de 1922, el gobierno del presidente José Tamayo masacró a las masas obreras levantadas en huelga en uno de los episodios más nefastos de la ciudad de Guayaquil.

1922 fue un año en el que brotaron acciones y pensamientos de una inquietud espiritual generalizada en Occidente. El surgimiento de poetas dadaístas en la ciudad de Portoviejo envuelve más de misterio a este período y a Portoviejo. Desde finales del siglo XIX e inicios del XX, esta ciudad es escenario de beligerancias políticas, luchas sangrientas entre liberales y

1. Hugo Mayo es el pseudónimo de Miguel Augusto Egas, poeta guayaquileño, el primer ultraísta del Ecuador. El zaguán de aluminio es un libro de poemas que estaba en la imprenta en el año 1922, pero extrañamente desapareció y no se publicó sino hasta 1982.

2. José María Velasco Ibarra fue presidente del Ecuador en cinco ocasiones y uno de los políticos más influyentes en el siglo XX. Pío Jaramillo Alvarado es un escritor y pensador de la ciudad de Loja. El indio ecuatoriano es un estudio que influyó en la sociología y el reconocimiento pluricultural del Ecuador. 
conservadores. La juventud portovejense fue testigo de asedios a la ciudad y cruce de fuego entre las falanges de pelotones rebeldes y las fuerzas del gobierno. Portoviejo era una ciudad agreste que recibía una lumbre opaca de modernidad con la llegada del tren en 1913 y el teléfono en 1915. Era una época de hobbies victorianos, juegos florales y asedios bandoleros con asalto a trenes a lo spaghetti western (Molina 2009, 86, 92, 94).

La revista Iniciación lanzó su primer ejemplar en noviembre de 1921. En una crónica de Ecuador Cultural de Dúmar Iglesias Mata, recogida por Ramiro Molina, se informa que "En noviembre de 1921, con el auspicio del gobernador de Manabí, Arnaldo Gálvez, coronel José Antonio Gómez González y otros intelectuales de la época, con la dirección del Dr. Wilfrido Loor Moreira, se publicó el primer número de la revista cultural Iniciación" (107). En las primeras páginas de la revista se hace un reconocimiento, una reseña y se publica un poema del gobernador. La tendencia de la revista era liberal. El coronel que se nombra es uno de los dos autores que publicaron poemas dadaístas en la revista con sus nombres reales. Sobre él, lamentablemente hay muy poca información. Por testimonio de historiadores con quien tuve la oportunidad de conversar, el coronel era un hombre cosmopolita que llegó a Portoviejo proveniente de Guayaquil y que sin duda influyó en el surgimiento del dadaísmo en esa ciudad. El otro autor que firma con su nombre los poemas es Horacio Hidrovo Velásquez, de quien se conoce más y se hablará más adelante.

El artículo introductor de la revista declara la intención de renovarse o morir y su obligación de ilustrar al público lector. En cuanto a lo de renovarse, se reconoce una apertura para las manifestaciones inauditas en el mundo. Como gesto de estar a la vanguardia, la revista usa la i latina como coordinante, costumbre entre autores de avanzada. Sin duda que además de la mejora en los medios de comunicación con el teléfono y los ferrocarriles, las condiciones se prestaban para que por medio de testimonios personales y por el contacto editorial con España y Europa apareciera el dadaísmo de Portoviejo. Sin embargo, el camino no estaba libre de detractores.

Calificada como "decadencia cerebral" por una reseña del diario $E l$ Comercio de Quito (año XVII, n. ${ }^{\circ}$ 6183, 28 de noviembre de 1922, 4), la poesía dadaísta desplegaba su irreverencia con intervalos desde marzo de 1922 hasta marzo de 1923 en la revista Iniciación. Este boletín tuvo una prolongada circulación, desde noviembre de 1921 hasta febrero de 1928, 
bajo la dirección de Wilfrido Loor Moreira (Calceta, 1900), que con tan solo veintiún años emprendió de manera prolífica la dirección hasta el cierre de la revista, una de las de mayor difusión cultural en la historia de la provincia. Para comprender el surgimiento del dadaísmo de Portoviejo es fundamental reconocer las dos orientaciones que se deprenden de esta corriente, sostenidas por Carlos Granés en El puño invisible, y el sistema de transmisión de las expresiones de la cultura, en especial, el circuito de la información transmitida entre Europa y Ecuador.

\section{EL DADAÍSMO DE ZÚRICH}

El dadaísmo surgió en la ciudad Zúrich en el año 1916. Su origen se debe a los alemanes Hugo Ball y Emmy Hennings, y al rumano Tristan Tzara. Como muchos artistas y disidentes políticos, ellos se refugiaron en Suiza de los horrores de la Primera Guerra Mundial. La aventura dadaísta inició cuando Hennings y su pareja, Hugo Ball, arrendaron un local en Spiegelglasse 1 (Calle del Espejo) donde inauguraron El Cabaret Voltaire el 15 de febrero de 1916. El modesto local, ubicado en la base de un edificio de cinco plantas, albergaba todo tipo de espectáculos: danza, obras dramáticas, recitales y conciertos. Al fondo del establecimiento había un pequeño escenario con un piano y encima una máscara africana acompañada de la palabra que resumía la extravagancia de los espectáculos: dada (Sarmiento 2016, 7-10).

Las innovaciones literarias que presentaron fueron las palabras en libertad inspiradas por Tomasso Marinetti, la poesía simultánea en la que se mezclaban dos o más obras poéticas al unísono o coordinadas acompañadas de onomatopeyas y ruidos y, además, los poemas bruitistas que consistían en versos elaborados sin ninguna palabra, solo con una serie de sonidos. Da gusto imaginarse toda la teatralidad de los recitados y obras dramáticas con colorido e indumentaria estrambótica. Gran parte de estas expresiones se caracterizaban por no responder a los preceptos de la tradición literaria por medio de la irreverencia hacia el sentido, la sintaxis y la lógica.

Carlos Granés (2011) en El puño invisible reconoce en este rompimiento de paradigmas y normas dos orientaciones que se bifurcan y se distinguen por motivaciones y propósitos diferentes. En uno de los senderos, 
la motivación de Tristan Tzara sobre el escenario era confrontar el gusto de la burguesía y la caducidad del academicismo. Este uso irreverente de la palabra era para él un medio eficaz para enfrentar al público y generar una mueca incómoda. Granés reconoce en esta actitud del autor rumano los principios cínicos de Diógenes de Sinope, un cinismo confrontativo que con el quebrantamiento de las normas del lenguaje, de sus principios sintácticos y semánticos se burlaba de la solemnidad del arte y del gusto de la burguesía. La irreverencia ante los paradigmas de la lengua era una finalidad en sí, un gesto político en el que el autor como una fiera rabiosa mostraba los dientes, acorazado en el escenario, al resguardo de una barricada, desplegando su irreverencia como dardos ante la hipocresía y valores caducos de la sociedad.

El otro sendero por el que recorría el dadaísmo, según Carlos Granés, era el del epicureísmo, definido por una introspección, una exploración del alma y de las concepciones de la inteligencia humana. En la poesía, el artista busca imágenes nuevas en un momento previo al signo lingüístico, en un más allá, por encima, por debajo, por un lado y el otro del significante y el significado. Como ejemplo de esta actitud en el arte plástico, Granés (46-7) reconoce a Marcel Duchamp, por esa mirada analítica que cuestionaba lo ordinario y buscaba develar una verdad profunda. No se trataba acá de una provocación a la sociedad, sino de una mirada introspectiva que buscaba alterar los principios que sustentan el pensamiento, las emociones y las ideas de un individuo. Las finalidades de estas actitudes son diferentes, pero la irreverencia ante los paradigmas de la lengua y la literatura se sostiene como principio común de ambas.

Como parte de la orientación epicúrea se reconoce a Hugo Ball. Un ejemplo que resulta ilustrativo es la velada del 16 de junio de 1916, en la que Ball recitó tres poemas bruitistas vestido de manera estrafalaria con un traje cónico que simulaba una especie de obelisco alado. Uno de los poemas lleva por título "Jolifanto bambla" y sus primeros versos dicen:

jolifanto bambla ô falli bambla

grossiga m'pfa habla horem

égiga goramen

higo bloiko russula huju

hollaka hollala

anlogo bung

blago bung 
blago bung

bosso fataka

ü üü ü

(Sarmiento 2016, 226)

Según su propio testimonio recogido por Antonio Sarmiento en Cabaret Voltaire, el autor declara lo siguiente con respecto al recitado de este poema:

me pareció como si apareciera en mi máscara cubista un rostro de joven pálido y descompuesto, esa cara mitad asustada y mitad curiosa de un chico de diez años que en las misas de difuntos y en los oficios solemnes de la parroquia de su lugar pende, tembloroso y ávido, de la boca del sacerdote. Entonces se apagó, como yo había deseado, la luz eléctrica y me bajaron, cubierto de sudor como un obispo mágico, del estrado al escotillón. (224)

Resulta curioso que el recitado de un poema que se desentiende por completo del sentido le haya provocado a su autor imágenes vinculadas a un culto religioso, a la infancia y al éxtasis místico. El uso irreverente de la lengua condujo la imaginación del poeta a una mirada interior, a una introspección, a un recorrido que a partir de una sonoridad aberrante despertaba en la imaginación una arquitectura divina y la infancia. Es más, el desplazamiento que él describe desde el estrado al escotillón tiene connotaciones que superan la descripción física del movimiento y sugieren una exploración de las profundidades de la imaginación del autor.

En los primeros versos del poema "Psiografías", Jorge Marzo expresa lo siguiente:

Parlan las oquedades diáfanas traslúcidas prístinas

que gravitan en el sentimiento ancestral

de nuestro pierio íntimo

"quintaesenciado"

Azur

Viajeras

alas de tíbar

agitándose inconmensurables

por la estela áurea eterna infinita

del errabundo viaje de la psiquis potencial

en una fuga milenaria de minutos ensoñados 
KİPUS 49, enero-junio 2021

que rielan en el espacio de trágicos pasados

una constelación pretérita de difusa armonía.

(Iniciación, n. ${ }^{\circ}$ 7, junio de 1922, 22)

El poema sugiere un trayecto lumínico en la psiquis humana, una introspección hacia lo prístino y el tiempo ensoñado. Como este poema, son varias las obras de los poetas de vanguardia de Portoviejo en los que se reconoce la misma trayectoria. Por tanto, el dadaísmo ecuatoriano se explica como un reflejo de la orientación estoica reconocida por Carlos Granés como una de las posibilidades de esta corriente, porque sus poemas se caracterizan por una exploración de la interioridad del ser y de las imágenes primordiales de la naturaleza, a pesar del manejo irreverente del lenguaje. Ahora bien, para establecer este vínculo entre lo sucedido en Zúrich y en Portoviejo, falta todavía reconocer otros pensadores que influyeron en la poesía de El Cenáculo Dada.

\section{GUILLAUME APOLLINAIRE}

Guillaume Apollinaire fue uno de los poetas más relevantes para el desarrollo de diversas propuestas estéticas de vanguardia. Él inspiró a muchos autores no solo con su poesía, sino también con sus ensayos en los que discutía, describía y definía el surgimiento de toda esa oleada estética como el resultado del nacimiento de un "espíritu nuevo". Dos ensayos de él son fundamentales para comprender principios estéticos que se reconocen en las obras cubistas y en la orientación introspectiva del dadaísmo. El primero es Les Peintres Cubistes: Méditations Esthetics, publicado en 1913 como libro con ilustraciones y reseñas de distintos pintores de esta corriente, entre los que constan Pablo Picasso y Marcel Duchamp. El otro ensayo es "L'esprit nouveau et les poetes" de 1918, publicado en la revista Mercure de France.

En el estudio dedicado a los pintores cubistas, se reconoce la declaración del principio de irreverencia ante la tradición y la proclamación de un arte que se explaya sobre el "cadáver del padre" (Apollinaire 1913, 7). La experimentación es la motivación principal, un medio para el hallazgo de algo esencial, como lo hace el pintor cubista, que llega a la esencia del diseño por medio de la geometría (15). Esto quiere decir que la finalidad 
del pintor no está en representar la geometría, sino en utilizarla para lograr expresar lo que Apollinaire llama "la cuarta dimensión" (15).

En "L'esprit nouveau et les poetes" se reconoce el arte como un medio de exploración introspectiva, como repliegue del alma hacia una verdad y unidad de las cosas que supera los límites de la razón como medio de conocimiento. La exploración de los abismos de la imaginación es un esfuerzo de la inteligencia que tiene como resultado una imagen literaria. El arte es un medio de conocimiento del universo con un "sentido sólido", como el de los clásicos para admirar la vida. Tanto los artistas de esta vanguardia como los antiguos ejercían con sus obras concepciones totalizadoras sobre el universo (385-6). Para el espíritu nuevo, el deseo de abarcarlo todo va más allá del régimen del sentido, del dominio de la palabra sobre el mundo, en especial de la palabra escrita, la que se viste de orden y control.

En consecuencia, los recursos literarios utilizados por los autores de vanguardia se desprendían de la norma y el sentido y jugaban incluso con lo ridículo, pues se evitaba la mediación de la razón como la herramienta principal para encontrar una imagen. Por este camino se caía muchas veces en lugares absurdos de incursiones estrafalarias. Pero el espíritu nuevo lo exploraba también porque forma parte de la vida tanto como en la literatura tradicional el heroísmo forma parte de la vida de los poetas (Apollinaire 1918, 390). Este nuevo espíritu no exaltaba más el universo de los héroes épicos, sino el del individuo ordinario de quien se exploraba lo cotidiano. Por tanto, la poesía del espíritu nuevo era el resultado de una cohesión de imágenes tan heterogéneas donde la cohesión imaginaria predominaba sobre la coherencia de las ideas (Bachelard 1992, 111). Un ejemplo es la extrañeza que generan estos versos del poema "Fotóptica" de Alfredo Septiembre (Iniciación, n. ${ }^{\circ} 8$, julio de 1922, 26):

\section{La Luna dialogando con Venus en el mundo sin metro congelado Argentado fin.}

Esta cohesión que lleva a la mente a imaginar astros, hielo, agua, plata, reflejo y fin propone una introspección, un juego que revolotea la imaginación hacia esencias universales, es un juego que tiene algo de di- 
vino, asociado con lo que Apollinaire llamaba lenguaje profético, “juego divino de la vida y de la imaginación" (Apollinaire 1918, 392). Se trata de un lenguaje gestual que deriva en lúdicos poemas procurando imágenes absolutas, alumbramiento de expresiones esenciales, de lo máximo y lo mínimo, de lo micro y macro cósmico, de lo oblicuo, de la no consecuencia en la sucesión de imágenes. Alumbramiento espontáneo de la imaginación.

\section{RAFAEL CANSINOS ASSENS, EL ULTRA INTERMEDIARIO}

Ese espíritu nuevo brotaba en Suiza, en Francia y luego en España. El sevillano Rafael Cansinos Assens fue un erudito que supo transmitir este sentir bajo el emblema ultra a jóvenes de Sevilla, de Madrid y de varias ciudades de América Latina. Entre los hispanoamericanos que tuvieron relación con Cansinos en esta época está Jorge Luis Borges, quien dice esto sobre el español:

Él había leído todas las bibliotecas de Europa. Recuerdo que dijo, en su estilo hiperbólico, que era capaz de saludar a las estrellas en diecisiete idiomas clásicos y modernos. No sé si realmente eran diecisiete, pero está bien la mención de las estrellas, que ya sugieren lo infinito. No sé si ustedes conocen toda la obra de Cansinos, yo no conozco nada, pero recuerdo quizá menos lo escrito que lo hablado por él, o lo sonreído por él [...]. Además, quizá más importante que un libro es la imagen que este libro deja; quizá más importante que lo dicho por un hombre es la imagen que esos dichos o ese silencio dejan. Yo creo que Cansinos fue un gran maestro oral; bueno, también lo fueron Pitágoras, Jesús, el Buda, Sócrates. De la obra de él no sé qué perdurará, pero sé que su memoria personal perdura. Y además ese estilo psálmico, digamos, esas largas frases, siempre armoniosas, que no se perdían nunca. Yo he conocido a muchos hombres de talento, pero hombres de genio, no sé, hay dos que yo mencionaría: uno, un nombre quizá desconocido aquí, el pintor y místico argentino Alejandro Xul-Solar, y el otro, ciertamente, Rafael Cansinos Assens. Y quizá, pero solo como maestro oral, Macedonio Fernández. Los demás eran meros hombres de talento. (Bernstein 2007)

El ultraísmo español fue un movimiento fugaz, una aventura de una juventud acomodada y muy bien instruida. Borges conoció a Cansinos As- 
sens en 1919, seguramente en Sevilla, donde la familia arribó luego de una prolongada estadía en Ginebra durante toda la Gran Guerra. Al cese de las hostilidades, la familia se trasladó desde la ciudad suiza a España, primero a Mallorca y luego a Sevilla, donde seguramente Jorge Luis conoció a Rafael Cansinos Assens. Lo más probable es que se hayan conocido en una tertulia, donde este maestro oral cautivaba a jóvenes en Sevilla y Madrid, e inspiraba concepciones poéticas de un más allá, de una libertad de la imaginación. En diciembre de 1919, Borges publicaba su primera colaboración registrada en España. En Suiza tenía ya publicada "Chronique des lettres espagnoles". ${ }^{3}$ En diciembre de ese año, Borges publicó "Himno del mar" en la revista Grecia de Sevilla. El poema está dedicado a Adriano del Valle un redactor de la revista Grecia. La primera estrofa refleja el gusto del ultraísmo por la imagen poética, por la impresión de lo vasto, de lo amplio y lo esencial, por la imagen desprendida de la pasión del sujeto:

Yo he ansiado un himno del Mar con ritmos amplios como las olas que
gritan;
del Mar cuando el sol en sus aguas cual bandera escarlata flamea;
del Mar cuando besa los pechos dorados de vírgenes playas que aguar-
dan sedientas;
del Mar al aullar sus mesnadas, al lanzar sus blasfemias los vientos,
cuando brilla en las aguas de acero la luna bruñida y sangrienta;
del Mar cuando vierte sobre él su tristeza sin fondo la Copa de Estrellas. (Grecia, n. ${ }^{\circ}$ 37, 31 de diciembre de 1919, 3-4)

Las estrofas siguientes del poema tienen una fuerte influencia de Walt Whitman por la presencia de un sujeto que interactúa con la naturaleza, chocan fuerzas igual de potentes, la voz poética contra la naturaleza, el sujeto del poema orientado a su emocionalidad, con expresiones eróticas $\mathrm{y}$ visiones de la vastedad.

Sobre la escritura del joven Jorge Luis Borges, de seguro que Adriano del Valle habría expresado su admiración con Rafael Cansinos Assens, quien era colaborador de Grecia y, además, a partir de enero de 1919, asumía como director de la sección española de la revista Cervantes. Desde ambas plataformas, Cansino encauzaba a algunos jóvenes hacia expresio-

3. Borges publica en La Feuille, Ginebra, 20 de agosto de 1919. Compilado por Sara Luisa del Carril en: Borges (2007). 
nes ultraístas. Tan solo dos meses antes de la publicación del poema de Borges en España, el 30 de octubre de 1919 se publicó, en la página 3 del ejemplar 31 del año 2 de la revista Grecia, el poema “Oxidación” de Hugo Mayo con un encabezado firmado por Rafael Cansinos Assens que decía "Desde Guayaquil, el original poeta Hugo Mayo nos honra enviándonos su adhesión al Ultra y esta singular poesía, que nos advierte de la sorprendente irradiación de la nueva lírica". De seguro Adriano y Rafael habrían comentado con sorpresa estos versos:

\title{
OXIDACIÓN
}

\author{
Partí en automóvil a Saturno. \\ La sombra \\ retrocedía diagonal a la sombra \\ acero. \\ Los dos ojos durmieron \\ derramando miles de estrellas. \\ La ciudad tiene muchas narices \\ que estornudan por contagio. \\ cuelgan brazos torcidos \\ Los árboles \\ que acarician mis ilusiones. \\ Y llevo triángulos en el cerebro \\ que sueñan. \\ El arco iris amaneció perezoso \\ oxidando al viento. \\ Me encarno en las cerraduras \\ de las puertas esquineras. \\ Los sonidos térmicos \\ ondulan subaereamente
}

(Grecia, n. ${ }^{\circ}$ 31, 30 de octubre de 1919, 3)

Este poema era parte del lote de cuatro poemas de Hugo Mayo enviado a Madrid. Tres de ellos fueron publicados en la revista Cervantes. La llegada de Cansinos para dirigir la sección española de la revista representó la mayor escalada del ultraísmo. Desde esa plataforma fue posible trasladar las propuestas a América. A los puertos de Guayaquil llegaba la revista española. Hugo Mayo leía la revista y en el lenguaje utilizado por los ultraístas él vio reflejado su propio lenguaje. 


\section{MIGUEL AUGUSTO EGAS (HUGO MAYO) Y LA LLEGADA DE ULTRA AL ECUADOR}

Miguel era un lector muy curioso con una necesidad de buscar una o un poeta semejante a él, de emociones y postulados parecidos, para quebrar la soledad que él compartía con nadie más que Hugo Mayo, su nombre de pluma, su pseudónimo, su heterónimo, su döpppelganger, su ser poético. Alrededor del mundo encontró amigos, en Uruguay, en Perú, en España y quien sabe cuántos países más. ${ }^{4}$ Cuando se publican los cuatro poemas de Mayo en las revistas Cervantes y Grecia, él estaba en Guayaquil, donde se sabe, por su propio testimonio, que llegaba la revista Cervantes (Calderón 1985, 159).

Hay un vínculo adicional entre Ecuador y el boletín madrileño. El quiteño César E. Arroyo, que desde 1912 se desempeñaba como diplomático en España, fue miembro fundador y director de la sección hispanoamericana de la revista Cervantes. Seguramente Rafael Cansinos Assens habría comentado con Arroyo los poemas de Hugo Mayo. Sin embargo, hay una mutua falta de reconocimiento entre Arroyo y Mayo. En noviembre de 1922, Arroyo expuso en el Royal Edén de Guayaquil una ponencia sobre el ultraísmo. En ella no hay mención de Hugo Mayo. Tal vez Miguel Augusto prefería mantener a Hugo en el anonimato. Si se conocían o no Miguel y César en esa época es incierto.

Los tres poemas publicados en Madrid tienen los recursos literarios que eran afín a los ultraístas. En su afán de presentar una imagen poética desprendida de la razón y de la pasión humana, cuya presentación es una expresión ontológica, los ultraístas desarrollaban ingeniosas greguerías. Un autor reconocido por el uso esquemático de la greguería es Ramón Gómez de la Serna quien había resumido la definición de la greguería en una breve fórmula: humorismo + metáfora. La greguería es la vía que conduce hacia el uso privilegiado de la imaginación, por eso es que algunos críticos lo consideran una influencia del ultraísmo (Torre 1968; Videla 1963). Se trata de una figura poética que no compara, que por un mecanismo arbitrario y libre de la imaginación anuncia una realidad nueva.

4. No contamos todavía con el archivo de Miguel Augusto Egas. No he tenido éxito en contactar al descendiente del autor ni a su familia cercana. La misma suerte han corrido otros investigadores. 
Hugo Mayo acude a este recurso para emocionar por la pura presentación de la imagen. En "De jardín” expresa estas dos greguerías:

Las ranas son los nuevos sopranos de la ópera lagunal.

El lirio, la copa de libaciones marinas (Cervantes, octubre de 1919, 51)

En “Oxidación” se encuentra la siguiente:

cuelgan brazos torcidos Los árboles que acarician mis ilusiones (Grecia, n. ${ }^{\circ} 31,30$ de octubre de 1919, 3)

Otra característica del estilo que se reconoce en estos poemas de Hugo Mayo es la referencia a expresiones de lo absoluto y lo diminuto, muchas veces yuxtapuestas, como un afán de querer abarcarlo todo con la imaginación. Como imágenes de lo absoluto se identifican los astros y la galaxia. Como expresiones de lo diminuto se manifiestan reacciones moleculares, químicas o microscópicas. Constátese por ejemplo que el primer verso de "Oxidación" indica: "Partí en automóvil a Saturno", y al final del poema se hace referencia a reacciones moleculares con los versos:

Me encarno en las cerraduras

de las puertas esquineras.

Los sonidos térmicos

ondulan subaereamente.

Lo mismo se reitera en el poema "Drogas":

Los tallos,

los órganos de la biología

i la savia elevada

serán las droguerías de Júpiter. 
Los carbonatos

saldrán de las auroras boreales.

del $8^{\circ}$ hacia el N. W.

El hidrato de quinina tendrá el laboratorio

de los alíseos,

i Celsius formará la amalgama

con el período undecinal.

(Cervantes, octubre de 1919, 52)

Un tercer rasgo es un manejo lúdico y gestual del lenguaje que el autor francés reconocía en todos los que encarnaban el espíritu nuevo. Es un lenguaje fundado sobre la emoción y el pensamiento espontáneo, con imágenes que al aparecer no tienen orden de aparición, ni secuencia, ni consecuencia entre ellas. Este medio de expresión es lo que Apollinaire llama lenguaje profético, medio de expresión que no se valida por el logos, sino por el acto de decir, y que por nada más que su enunciación se manifiesta una verdad. Es un lenguaje divino porque es el que hablan las pitonisas bajo el influjo de hierbas poderosas, es la verdad en el vuelo del pájaro, en las vísceras de un animal sacrificado, en la llama de un fuego sagrado. De esta forma Hugo Mayo dice en “Oxidación”:

\section{El arcoíris amaneció perezoso oxidando el viento}

Estos rasgos se reiteran en los poemas de esta época de Hugo Mayo y en los dadaístas de Portoviejo. En estos poetas despertaba el espíritu nuevo, una aspiración ultraísta. Por lo intrigante de las imágenes y la inexplicable fruición que me provoca, considero que el poema mejor logrado del ultraísmo ecuatoriano es "Oxidación". Cansinos seguramente habría pensado que de los cuatro poemas recibidos, “Oxidación” debía ser separado del montón para enviarlo a Sevilla a ser publicado en su ciudad natal con el encabezado que reconocía a Hugo Mayo como parte de Ultra.

\section{LA LLEGADA DEL ULTRAÍSMO A MANABÍ}

En España, el ultraísmo gozó de un fervor que provocaba opiniones de diversos pensadores como José Ortega y Gasset (2007) en la obra La 
deshumanización del arte, en la que hace un esfuerzo por entender los disparates de los ultraístas. Fueron tres años de agitación, movimiento editorial y veladas. La tercera y última velada se celebró en el Ateneo de Madrid, su presencia en un lugar de prestigio demostraba la atención que atraía. Cansinos Assens avivaba el fervor con las traducciones de diversos autores como Filippo Tommaso Marinetti, Pierre Reverdy, Tristan Tzara, Vicente Huidrovo y Guillaume Apollinaire. De este último, Cansinos tradujo “El espíritu nuevo y los poetas" (Cosmópolis, n. ${ }^{\circ} 1$, enero de 1919, 17-28).

Según la reconstrucción histórica (Torre 1968; Videla 1963), el ultraísmo surgió como una posibilidad en una entrevista entre Xavier Bóveda y Rafael Cansinos Assens en el otoño septentrional de 1918. Ahí se reconoce al creacionismo de Vicente Huidrovo como una influencia fundamental. En enero de 1919, en el primer número de la revista Cervantes que Cansinos dirigía, se reprodujo el manifiesto ultraísta que había sido publicado en diversos medios impresos, según dice el encabezado. En el cuerpo del texto, los ultraístas manifestaban:

Nuestro lema será "ultra", y en nuestro credo cabrán todas las tendencias, sin distinción, con tal que expresen un anhelo nuevo. Más tarde estas tendencias lograrán su núcleo y se definirán. Por el momento, creemos suficiente lanzar este grito de renovación. (Cervantes, enero $1919,3)$

En Portoviejo, en cambio, en el número 5 de la revista Iniciación (junio de 1922, 15-8), se publicó "Explicando el jeroglífico", texto que podría considerarse el manifiesto estético del grupo de poetas que se autodenominó El Cenáculo Dada (así, con entonación grave) al firmar el texto. En el primer párrafo se destaca el ultraísmo por su cualidad aglutinante:

Investigando pacientemente en las fuentes más autorizadas, exóticas y propias, que pudiesen surtir de ilustración sobre el dadaísmo, cubismo, simbolismo, ultraísmo, hay-kais, formas modernísimas adoptadas por las avanzadas líricas francesas y españolas; hemos venido en conocimiento que las tan debatidas formas así denominadas son ya de vieja existencia, si pensamos que todas estas tendencias clasificadas particularmente pueden condensar en una sola escuela o tendencia, bien denominada genéricamente ULTRA-MODERNISMO o ULTRAÍSMO, cuyas bases sentaron ya hace muchos años Paul Verlain (el gran lírico francés) y su continuador Stephans (sic) Mallarmé, con el simbolismo. (15) 
Este párrafo introductor contiene una clara paráfrasis del lema del manifiesto ultraísta. Es evidente que el metatexto con el que el autor estaba trabajando era el manifiesto ultraísta. Puede ser incluso que entre esas “fuentes más autorizadas, exóticas y propias" estuvieran correspondencias con Hugo Mayo y Miguel Ángel León, autores a los que se hace referencia nombrándolos o mencionando sus publicaciones. ${ }^{5}$

Dado que Cervantes llegaba a Guayaquil, no solo Hugo Mayo encontraba en los versos de los ultraístas reflejado un lenguaje con el que podía expresar el vasto mundo de la imaginación. Seguramente José Gómez González conocía esta revista y las novedades llegaron a Manabí, a Portoviejo, a la atención de los jóvenes involucrados en la edición de la revista Iniciación, en especial a Horacio Hidrovo y a Wilfrido Loor. Admirados por la poesía de Hugo Mayo, a ellos también les entusiasmaría la producción poética de Jorge Marzo, José Julio, Rodrigo Enero y Alfredo Septiembre de la revista Iniciación.

El manifiesto como género literario era común a casi todos los movimientos de vanguardia, pero lo que llama particularmente la atención de “Explicando el jeroglífico" es su tono académico, ese esfuerzo consciente de explicar la estética que la agrupación proponía. El texto empieza por justificar sus opiniones resaltando "las fuentes más autorizadas, exóticas y propias”, luego construye una tradición propia iniciada, según ellos, con los poetas simbolistas franceses, después caracteriza las diversas corrientes novedosas de inicios de siglo y concluye reafirmando la intención de desplegar una poética experimental que encentraría siempre sus retractores.

Hay una contradicción entre la práctica y la denominación utilizadas por los dadaístas ecuatorianos y los europeos al referirse al cenáculo como institución de diálogo e intercambio de saberes. El ultraísmo español criticaba la institución del cenáculo por ser una práctica decimonónica que se enclaustraba en una contemplación y complacencia endogámica. Para los ultraístas, el espacio para la comunicación de los saberes era la velada, un evento público, un espacio para la polémica. De esta se deriva una segunda contradicción. En "Explicando el jeroglífico" se percibe una mentalidad de cenáculo en el hecho que se venera una tradición. Hay una constante justificación del valor de sus prácticas por el origen europeo. Estar a la vanguardia

5. Miguel Ángel León (1900-1942) es un poeta de la ciudad de Riobamba, uno de los precursores de la vanguardia en el Ecuador. 
como los europeos era muestra de distinción. Los poetas ecuatorianos dejaban de lado la actitud incendiaria que no creía en una tradición hegemónica.

Sin embargo, en cuanto a la concepción del arte como un medio libre de normas para la exploración de la imaginación, el ultraísmo ecuatoriano tiene una conexión profunda con el dadaísmo introspectivo. Entre las distintas definiciones que el manifiesto ofrece sobre las diversas orientaciones de inicios de siglo, dice: "El ultraísmo, tendencia análoga a la forma DADA es “el más allá” del modernismo [...] en donde "más que la línea material de las palabras se recoge la ondulación de las emociones, de las ideas, y las sutiles curvas de la sensibilidad que rehúyen el yugo gramatical y retórico" (Iniciación, junio de 1922, 17). Como precursores del dadaísmo en el Ecuador, el manifiesto menciona dos autores: Miguel Ángel León y Hugo Mayo. Siguiendo el rastro de este último, se hizo evidente la influencia del ultraísmo español en los poetas dadaístas del Ecuador.

\section{EL CENÁCULO DADA}

El primer anuncio de lo que sería El Cenáculo Dada se da con el poema "Las nuevas formas" de Horacio Hidrovo. El tono bautismal declara el nacimiento de una poesía ultraísta en la revista:

\section{LAS NUEVAS FORMAS}

En el laboratorio del cerebro formemos la substancia para un verso del vigésimo siglo, del siglo del progreso.

Aristocráticos del sentimiento poetas de las románticas estrofas: habrá una dolorosa innovación.

El sepulturero Tiempo

tomará entre sus dedos aquel pájaro azul que canta en el fondo del corazón para llevarle embalsamado al gran museo del Pasado. Alguna vez el amo Recuerdo llegará a visitarlo...

Aviones de records supremos los futuros cerebros 
agitarán sus alas hacia el país Renuevo

Un

a te

ri

$\mathrm{za}$

je

feliz.

En Helicón hay cruces varias,

epitafios grises.

Clasicismo, romanticismo, decadentismo.

Llega a Castalia un rubicundo infante

Un moderno y dorado Heliofante

le da un ULTRA bautismo

(Iniciación, n. ${ }^{\circ}$ 4, febrero y marzo de 1922, 20)

Este poema precede a "Explicando el jeroglífico". Por su contenido, este texto podría ser considerado el manifiesto en verso. La metáfora científica con la que inicia el poema reafirma la voluntad introspectiva para producir su poesía. En este poema se reconocen los objetos poéticos y los recursos literarios que Hugo Mayo utilizaba y que eran tan afín al ultraísmo.

En la poética de El Cenáculo Dada he reconocido una característica que he definido como la progresión metáfora, greguería y lenguaje poético (Haro 2019, 38-42). En algunos de los poemas de esta agrupación, se encuentran varias metáforas en las que los elementos de la comparación de fenómenos sensibles o conceptuales se asocian de manera racional. Sin embargo, se puede constatar que el grupo evitaba la metáfora justamente por el principio lógico que la determina. Hay una preferencia por la greguería, como un medio para suscitar no a través del lenguaje, sino de la sugerencia, la emergencia de la imagen poética.

Para demostrar el uso de esta progresión citaré algunos versos como ejemplos siguiendo lo expuesto en Espacio y tiempo imaginados en El Cenáculo Dada (1922) (Haro 2019). El poema "Noches de luna" de J. A. Gómez González presenta una metáfora plena:

Galanes timoratos que silentes

Marchan junto a la rosa

que anhelan deshojar

(Iniciación, n. ${ }^{\circ}$ 5, abril de 1922, 16). 
La tensión entre el galán y la rosa es el principio de la figura literaria. La rosa es pretendida por el galán. Mediante un desplazamiento de sentido, sugerido por el campo semántico de galán, el significado de rosa transmuta hacia mujer. La hoja, por analogía, es a la flor lo que la ropa es a una mujer. En consecuencia, se entiende que el deshojar de la flor es el desvestir de la mujer. La metáfora se cumple a plenitud por sus relaciones lógicas.

En cambio, Jorge Marzo presenta un claro ejemplo de una greguería en el poema “Óptica húmeda". Este poema, por la predilección de la greguería y el lenguaje profético, empieza a moldear el estilo propio de los jóvenes dadaístas. Jorge Marzo dice:

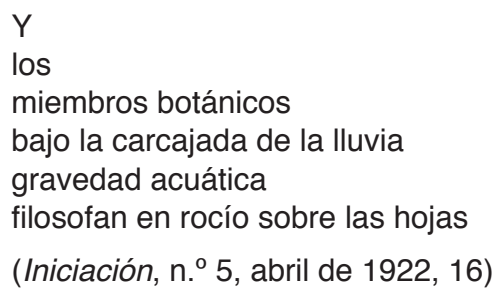

No se evidencia una relación lógica entre los elementos relacionados en la imagen. La comparación entre las plantas (miembros botánicos) y un filósofo, sugerido por el verbo filosofar no se apoya en la analogía. La comprensión de la imagen depende del poder de sugestión. Uno puede imaginar que las plantas parecen filósofas porque se encorvan con el peso de la lluvia, sugerida por gravedad acuática y carcajada. Sin embargo, para llegar a esta comparación se apela a la imaginación del lector. Así se puede llegar a formular la siguiente analogía: el rocío se desprende de las plantas como los pensamientos se desprenden de un filósofo. Para concebir esta imagen y esta analogía es fundamental partir por la imaginación. El ejercicio lógico y comparativo en estos versos no es suficiente para concebir la imagen propuesta.

Si bien la greguería era un recurso que permitía producir imágenes literarias que privilegiaban las capacidades de la imaginación sobre las racionales, el recurso les resultaba insuficiente para satisfacer el impulso poético de alcanzar imágenes absolutas. Engullidos por el abismo de la imaginación, los poetas de El Cenáculo Dada trascendían por medio del lenguaje profético la condición lingüística de la imagen. 
Como ya había mencionado, el lenguaje profético es aquel que utiliza la imaginación a modo de una reacción gestual del mecanismo mental donde la imagen brota, como una activación espontánea, libre de raciocinios y preconceptos. El presente verbal es el tiempo en el que se anuncia el lenguaje profético, porque es un acto que en su sola mostración acarrea una verdad. Las imágenes presentadas sin ninguna lógica cobran sentido por medio de su enunciación. En el poema "Noches de luna" de Gómez González, del cual había destacado una metáfora, encontramos un fragmento que ejemplifica el uso del lenguaje profético:

\author{
Espirales de Nicot \\ Vapores báquicos y afonías de Koch \\ Hay una ronda de tragedia \\ Los dedos clepsidrales \\ Del gran índice municipal \\ Avanzan len-ta-men-te- \\ Con el crescente mutismo nocturnal \\ (Iniciación, n. ${ }^{\circ}$, abril de 1922, 16)
}

Además, en el citado poema "Óptica Húmeda" de Jorge Marzo encontramos este uso del lenguaje profético al que luego le sucede la greguería expuesta anteriormente:

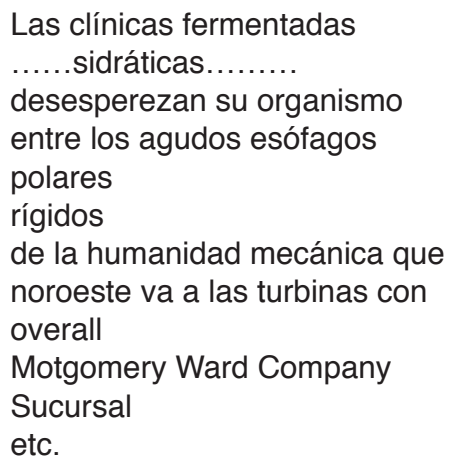

(Iniciación, n. ${ }^{\circ}$, abril de 1922, 16)

Como se puede constatar, el uso de una metáfora, greguería y el lenguaje profético puede entremezclarse en un solo poema. Hay una gradación del uso de estos recursos que elabora imágenes con una gradación 
que recorre desde un predominio de la relación lógica, que representa la metáfora, hasta una absoluta libertad de la imaginación, cuando el poeta se expresa con un lenguaje profético. La greguería vendría a ser como ese punto intermedio, como la llave que accede a lo irracional, llave que es gestual y libre de preceptos y normas. La greguería conduce a espacios poéticos de ultra.

\section{PROPUESTA DE UN POSIBLE DEVELAMIENTO DE LOS PSEUDÓNIMOS DE EL CENÁCULO DADA}

$\mathrm{Al}$ investigar archivos, bibliotecas y hemerotecas, no he podido dar con un documento que revele la identidad real de los pseudónimos. Sin embargo, apoyado en las evidencias dadas por el uso del lenguaje, una posible respuesta se puede proponer. Es casi una certeza que Horacio Hidrovo Velásquez encubre al menos uno de los nombres de pluma. El hecho de ser él quien primero mencionó el ultraísmo en Iniciación en el poema "Las nuevas formas" (Iniciación, n. ${ }^{\circ} 4$, febrero y marzo de 1922, 20) es bastante revelador. Resulta que, en el siguiente número, aparece en la revista Jorge Marzo por primera vez en compañía de José Gómez González y un Dadaísta Aficionado. La ausencia de Hidrovo Velásquez en esta edición es intrigante. $\mathrm{Al}$ parecer, lo que ocurre es que se establece un patrón de presentación en el que primero aparece el poeta ultraísta con su nombre legal y luego en el número siguiente del boletín aparece el pseudónimo. El patrón se reitera en la primera y única participación de José Gómez González con el poema "Noches de luna" (Iniciación, n. ${ }^{\circ} 5$, abril de 1922, 16), que antecede la aparición de José Julio en junio de 1922 en el séptimo ejemplar de la revista. Considerado este patrón en el que primero aparece el nombre civil y luego el pseudónimo en la siguiente publicación de la revista, sugiero que Jorge Marzo encubre a Horacio Hidrovo Velásquez y José Julio a José Gómez González.

Esta sospecha puede también confirmarse por medio de un análisis estilístico de Jorge Marzo y José Julio. Por este medio se puede identificar que estos son dos autores distintos. Al igual que Hidrovo, Jorge Marzo expone varias imágenes con características industriales y marítimas que in- 
cluso llegan a nombrar empresas foráneas con nombres extranjeros. En el poema "LAS 5. Pm.”, Horacio Hidrovo expresa:

Gran alumbramiento de la exportación

Feto de 25,000 miembros

que se pondrá en marcha inmediatamente, dirección New York

(Iniciación, n. ${ }^{\circ}$, junio de 1922, 22)

En cambio, en "Óptica húmeda” de Jorge Marzo encontramos los siguientes versos:

noroeste va a las turbinas con

overall

Motgomery Ward Company

Sucursal

etc.

(Iniciación, n. ${ }^{\circ}$, abril de 1922, 16)

Por otro lado, José Julio reitera el uso de la imagen agreste expresada con un vocabulario poco adecuado para el panorama. Así se demuestra en el poema "Visión vesperal":

$\quad$ Paréntesis ambulantes
los testuces astados
pausados
van a la destilación lâctea
Engreído
sueltan un canto agresivo
el matón del corral
tras las ovíparas odaliscas
camino del Harem

(Iniciación, n. ${ }^{\circ}$ 7, junio de 1922, 22)

Las imágenes agrestes con un lenguaje que no es corriente para la ocasión es también un rasgo que José Julio comparte con Gómez González y que se demuestra en estos versos de "Noches de luna": 
KİPUS 49, enero-junio 2021

La plegaria canina

Al astro blanco, en dueto

Con la canción hidroláctica de los batracios

Debajo del alero alguna Venus

Que termina su cuita entre los jueces

(Iniciación, n. ${ }^{\circ}$ 6, abril de 1922, 16)

Con respecto al resto de poetas, hay también coincidencias. Rodrigo Enero y Jorge Marzo son los únicos poetas en utilizar el vocablo infundibuliforme, expresión de origen latino, en el poema "Madrugada" (septiembre de 1922, n. ${ }^{\circ} 10,13$ ) del primero y "Plenilunio" (noviembre de 1922 , n. ${ }^{\circ} 11,23$ ) del segundo. Pero además se reconoce una coincidencia de Rodrigo Enero con José Julio en el uso de referencias científicas y numerales en la determinación de una ubicación y tiempo. En el poema "Madrugada" Rodrigo Enero dice:

\author{
Temperatura polar \\ del verano \\ en raid \\ de dos a siete a. $\mathrm{m}$. \\ (Iniciación, n. ${ }^{\circ} 10$, septiembre de 1922, 13)
}

Compárese esta expresión con la siguiente de José Julio en el poema "Visión vesperal":

Trayectoria astronómica 10 horas......

Trasformación cromática 5 p.m.

El gigante padre Helios

Va hacia el otro hemisferio......

(Iniciación, n. ${ }^{\circ}$, junio de 1922, 22)

También se reconoce una coincidencia entre Alfredo Septiembre y Jorge Marzo por la recurrencia de nombres industriales y marítimos como se ha destacado arriba en Jorge Marzo en el poema "Óptica húmeda". Alfredo Septiembre expresa en los versos de "Fotóptica" lo siguiente: 


\begin{abstract}
El faro guiña
su blanca pupila

SVENKA AKTIEBOGALET GAS ACCUMULATOR

Un trueno terrestre arrastrado por cuatro figuras

Geométricas iguales

FORD MOTOR CORPORATION Ltd.
\end{abstract}

(Iniciación, n. ${ }^{\circ} 8$, julio de 1922, 25).

Por medio de un análisis del estilo se pueden establecer relaciones entre algunos poetas dadaístas. Es probable que Horacio Hidrovo Velásquez y José Gómez González encarnen uno o hasta dos pseudónimos. También el vínculo cercano de Gómez González y el comité editorial de la revista abre la posibilidad de que Wilfrido Loor también haya participado como uno de los pseudónimos. Sin embargo, hasta no encontrar una prueba concreta como una epístola o un registro que revele el verdadero nombre de los nombres de pluma, estos seguirán siendo un misterio.

Lo que sí es casi una evidencia es que Horacio Hidrovo Velásquez era uno de los autores más activos de la poesía ultraísta ecuatoriana. En la visita que realicé al archivo del poeta en La Casa de Horacio en octubre de 2018, junto con la nieta del autor, la historiadora Tatiana Hidrovo, hallamos un pequeño librito, escrito a máquina y atado con hilo, que lleva por título Cauce que fue publicado en el año $1929 .{ }^{6}$ Según una reseña de pocos días después del lanzamiento de este librito, hubo 200 ejemplares. Los once poemas que componen el poemario, reflejan el estilo propio del ultraísmo ecuatoriano. Aparte de esta obra, se encuentran archivados otros poemas que demuestra que esta orientación estética de Horacio Hidrovo se desarrolló a lo largo de toda la década del veinte.

Como lo ha demostrado Humberto Robles (2006), cierto sector de la crítica literaria rechazaba la vanguardia de inicios del siglo XX. Prueba de ello es la crítica, referida en este artículo, en la que se califica al dadaísmo de la revista Iniciación como decadencia cerebral (El Comercio, 28 de noviembre de 1922, año XVII, n. $\left.{ }^{\circ} 6183,4\right)$. Sin embargo, es evidente que hubo un grupo, si bien pequeño, de poetas que encontraban en esa libertad de expresión un medio para explorar nuevos universos poéticos. Así,

6. La Casa de Horacio es la antigua casa de Hidrovo Velásquez. Tatiana Hidrovo conserva allí el archivo tanto de su abuelo como de su padre, el poeta Horacio Hidrovo Peñaherrera. 
pues, surgió el dadaísmo ecuatoriano como un reflejo de la orientación introspectiva del dadaísmo por la que transitaron algunos artistas europeos y americanos. Esta corriente era una derivación del "espíritu nuevo" que Guillaume Apollinaire reconocía en el arte naciente de la segunda década del siglo XX. Con la intervención de Rafael Cansinos Assens, esta noción de arte y poesía se trasladó a América Latina bajo el nombre de ultraísmo. En Ecuador no solo Hugo Mayo encontró su lenguaje poético reflejado en los versos ultraístas, sino también José Gómez González y Horacio Hidrovo Velásquez quien, a pesar de los detractores, mantuvo viva esta orientación hasta 1929, año de la publicación de Cauce. Todavía es deuda de los estudios literarios ecuatorianos indagar sobre esta faceta del autor nacido en Santa Ana para una comprensión más cabal de la dinámica de los sistemas literarios de inicios del siglo XX que perfilaron la literatura nacional.

\section{Lista de referencias}

Apollinaire, Guillaume. 1913. Les peintres Cubistes: méditations esthétiques. París: E. Figuiére.

—. 1918, "L'Esprit nouveau et les poètes". En Mercure de France. Tomo CXXX (noviembre-diciembre): 385-96.

Bachelard, Gaston. 1992. Fragmento de una poética del fuego. Buenos Aires: Paidós.

Bernstein, Ariel. 2007. "España en Borges". Clarín. Revista de Literatura. 7 de mayo. https://revistaclarin.com/569/espana-en-borges/.

Borges, Jorge Luis. 1919. "Himno del mar". Grecia (37) (31 diciembre): 3-4.

—. 2007. Textos recobrados (1919-1929). Buenos Aires: Emecé.

Calderón Chico, Carlos. 1985. "Conversación con el poeta Hugo Mayo". En Literatura, autores y algo más. Quito: Offset Graba.

Enero, Rodrigo. 1922. "Madrigada". Iniciación l (10): 13.

Gómez González, José. 1922. "Noches de luna”. Iniciación 1 (5): 16.

Granés, Carlos, 2011. El puño invisible. Arte, revolución y un siglo de cambios culturales. Madrid: Taurus.

Haro, José, 2019. "Espacio y tiempo imaginados en El Cenáculo Dada (1922). Ultra poesía de Portoviejo en la revista Iniciación (1921-28)". Tesis de maestría, Universidad Andina Simón Bolívar, Sede Ecuador.

Hidrovo Velázquez, Horacio. 1922. "Las nuevas formas". Iniciación 1 (4): 20.

—. 1922. "Las 5 p.m.". Iniciación 1 (7): 22.

- 1929. Cance. Guayaquil.

Julio, José. 1922. "Visión vesperal". Iniciación l (7): 22. 
Marzo, Jorge. 1922. "Óptica húmeda”. Iniciación l (5): 16.

—. 1922. "Psicografías". Iniciación l (7): 22.

Mayo, Hugo. 1919. "De jardín", "Drogas" y "Viaje". Cervantes (octubre 1919): 51-53.

—. 1919. "Oxidación". Grecia (31): 3.

Molina Cedeño, Ramiro. 2009. Historia de Portoviejo. Quito: Ediciones La Tierra.

Ortega y Gasset, José. 2007. La deshumanización del arte y otros ensayos. Madrid: Espasa-Calpe.

Robles, Humberto. 2006. La noción de vanguardia en el Ecuador. Recepción, trayectoria y documentos 1918-1930. Quito: Universidad Andina Simón Bolívar, Sede Ecuador / Corporación Editora Nacional.

Sarmiento, José Antonio. 2013. Las veladas ultraistas. Cuenca: Universidad de Castilla, La Mancha.

- 2016. Cabaret Voltaire. Cuenca: Universidad de Castilla, La Mancha.

Septiembre, Alfredo. 1922. "Fotóptica". Iniciación l (8): 25.

Torre, Guillermo de. 1959. Claves de la literatura hispanoamericana. Madrid: Taurus Ediciones.

—. 1968. Ultraismo. Existencialismo y objetivismo en literatura. Madrid: Guadarrama.

Videla, Gloria. 1963. El ultraísmo, estudios sobre movimientos poéticas de vanguardia en España. Madrid: Gredos.

VV. AA. 1922. "Explicando el jeroglífico". Iniciación l (8): 15-8. 